\title{
The research of traffic offences by pedestrians on the unregulated crossings with humps
}

\author{
Antonina Korzhova ${ }^{1}$, and Denis Kapski, ${ }^{2 *}$ \\ ${ }^{1}$ Scientific-research Center of road traffic, Belarusian National Technical University, Belarus \\ ${ }^{2}$ Automotive and Tractor Faculty, Belarusian National Technical University, Belarus
}

\begin{abstract}
The article presents the results of the study of traffic offenses by pedestrians on the unregulated crossings equipped with humps. The analysis of behavioral features of pedestrians is made taking into account traffic conditions and intensity of transport and pedestrian streams.
\end{abstract}

\section{Introduction}

The traffic management is a management of people who the most part of time are uncontrollable and react according to the knowledge and beliefs in traffic [1]. In this regard statement, the social relations in traffic are defining.

The social relations can divide into several groups conditionally: the relations between the state and traffic participants (drivers, pedestrians, passengers) and the relations between traffic participants (the driver - the driver, the driver - the passenger, the driver - the pedestrian, the driver - the cyclist, the pedestrian - the cyclist). In city conditions, about $80 \%$ of all accidents in the country are made. And pedestrians are exposed to the greatest danger (50\% of accidents with victims) [2].

\section{The research of pedestrians behavior in crosswalks zones}

The communication between drivers and pedestrians and also the state and pedestrians is defined the Traffic regulations generally. The chapter 4 regulates basic pedestrian's rights and duties [3]. The pedestrian has advantage before drivers when crossing a carriageway if he was convinced that the cross the carriageway is safe (points 16.1 and 17.2).

The definition of safety of a pedestrian exit to the carriageway is subjective. It has no accurate formulation and does not give a fair form of the transition moment on the road from safe to dangerous. According to the Traffic regulations, traffic safety is the condition of traffic providing the minimum probability of emergence of danger in process and the road accident. The danger to the traffic is the change of traffic conditions or technical condition of the vehicle menacing to traffic participants safety and forcing the driver to reduce the speed or to stop.

First of all when carrying out a research social relationship between pedestrians and drivers and behavior of pedestrians upon crossing of the carriageway on crosswalks with "guard", with a hump (as a physical measure of the speed reduction of traffic flow) was determined.

Objects of a research were chosen according to transport and pedestrian loading characteristics and an location of a hump in a crosswalks zone (fig. 1), also the category of the street and quantity of strips for traffic in a research zone (table 1) was taken into account. Basic data have been processed in the program complex "RTF-Road traffic flows" [4].

The using of humps is most effective on sites of accidents concentration (from the point of view of total losses - emergency, economic, ecological) which main reason is exceeding the traffic speed. By the legislation of the Republic of Belarus, the traffic speed in such places is limited up to $20 \mathrm{~km} / \mathrm{h}$, like pedestrian and residential zones. As the exception the humps

${ }^{*}$ Corresponding author: d.kapsky@gmail.com 
application is allowed on sites of the accidents concentration on streets and roads of settlements with the general speed restriction of $60 \mathrm{~km} / \mathrm{h}$ if all other measures for decrease in accident rate either are impossible, or are inefficient. At the same time the daily traffic intensity shouldn't exceed the following values, depending on building type:

$\checkmark$ multystoried, dense, bilateral -500 buses/days;

$\checkmark$ multystoried, dense, unilateral or multystoried, free, bilateral - 750 buses/days;

$\checkmark$ multystoried, free, bilateral or one-storey, bilateral - 1000 buses/days;

$\checkmark$ one-storey, unilateral -1250 buses/days.

$\checkmark$ vacant (in a radius up to $50 \mathrm{~m}$ ) the territory of the settlement - 1500 buses/days.

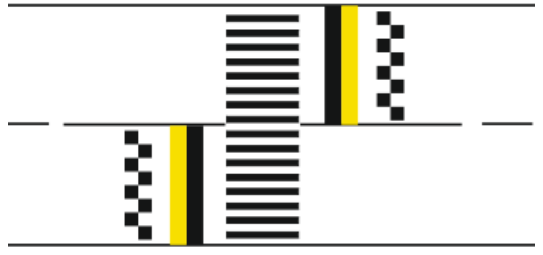

a)

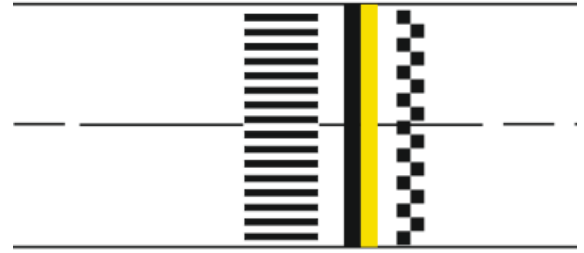

b)

Fig. 1. The standard variants of humps allocation in a crosswalk zone (a) - variant $1 ;-$ variant 2).

Table 1. The characteristics of the searched pedestrians crossings (Minsk, Belarus).

\begin{tabular}{|c|c|c|c|c|c|}
\hline $\begin{array}{c}\text { Наименование } \\
\text { объекта }\end{array}$ & $\begin{array}{c}\text { Кол-во } \\
\text { полос, } \\
\text { шт. }\end{array}$ & $\begin{array}{c}\text { Расположение } \\
\text { ИН }\end{array}$ & $\begin{array}{c}\text { ИД } \\
\text { транспорт } \\
\text { а, авт. /час }\end{array}$ & $\begin{array}{c}\text { ИД } \\
\text { пешеходо пеш. /ч }\end{array}$ & К $_{\text {пн }}$ \\
\hline ул. Н. Орды, 11 & $2 / 2$ & вариант 1 & 912 & 180 & 1,08 \\
\hline $\begin{array}{c}\text { ул. П. Бровки, 12/1 } \\
\text { (односторонняя) }\end{array}$ & $3 / 0$ & вариант 2 & 886 & 168 & 1,01 \\
\hline ул. Руссиянова, 48 & $3 / 2$ & вариант 1 & 392 & 172 & 1,16 \\
\hline ул. Одинцова, 65 & $2 / 2$ & вариант 1 & 1048 & 112 & 1,05 \\
\hline ул. Я.Коласа, 12 & $2 / 2$ & вариант 1 & 1384 & 220 & 1,05 \\
\hline $\begin{array}{c}\text { ул. Карбышева, } \\
13 / 2\end{array}$ & $2 / 2$ & вариант 1 & 404 & 156 & 1,12 \\
\hline ул. Кульман, 22 & $1 / 1$ & вариант 2 & 480 & 210 & 1,00 \\
\hline $\begin{array}{c}\text { пр. Пушкина, 19 } \\
\text { вдоль школы) }\end{array}$ & $1 / 1$ & Ин2 & 480 & 128 & 1,00 \\
\hline $\begin{array}{c}\text { ул. Богдановича, } \\
258\end{array}$ & $1 / 1$ & Ин2 & 900 & 72 & 1,16 \\
\hline $\begin{array}{c}\text { ул. Одоевского, } \\
107\end{array}$ & $1 / 1$ & вариант 1 & 2268 & 210 & 1,1 \\
\hline ул. Я.Коласа, 18 & $2 / 2$ & вариант 1 & 1264 & 296 & 1,1 \\
\hline $\begin{array}{c}\text { ул. Хмельницкого, } \\
47 / 1\end{array}$ & $1 / 1$ & вариант 1 & 420 & 49 & 1,02 \\
\hline
\end{tabular}

The using of humps on streets with traffic intensity with more than 200th vehicles/hour leads to increase of total losses in traffic due to growth of economic and ecological losses because of braking before a hump and the subsequent dispersal. It should be noted that the using of humps leads to economic and ecological losses round the clock and does not depend on presence of the traffic participants (pedestrians, cyclists, etc.) for whose protection they also are intended [5 - 12].

At a research of behavioral pedestrians reactions upon crossing of the carriageway the following movements were traced and fixed:

$\checkmark \quad$ whether the pedestrian was convinced of danger lack when approaching to crossing; 
$\checkmark$ whether the first action is duplicated;

$\checkmark \quad$ other behavioral reactions at stay on the carriageway.

The analysis of the received results has shown that $28 \%$ of pedestrians don't comply with paragraph 17.2 of the Traffic regulations, that is aren't convinced of safety of an exit to the carriageway, and 53\% don't look around even during crossing (fig. 2).

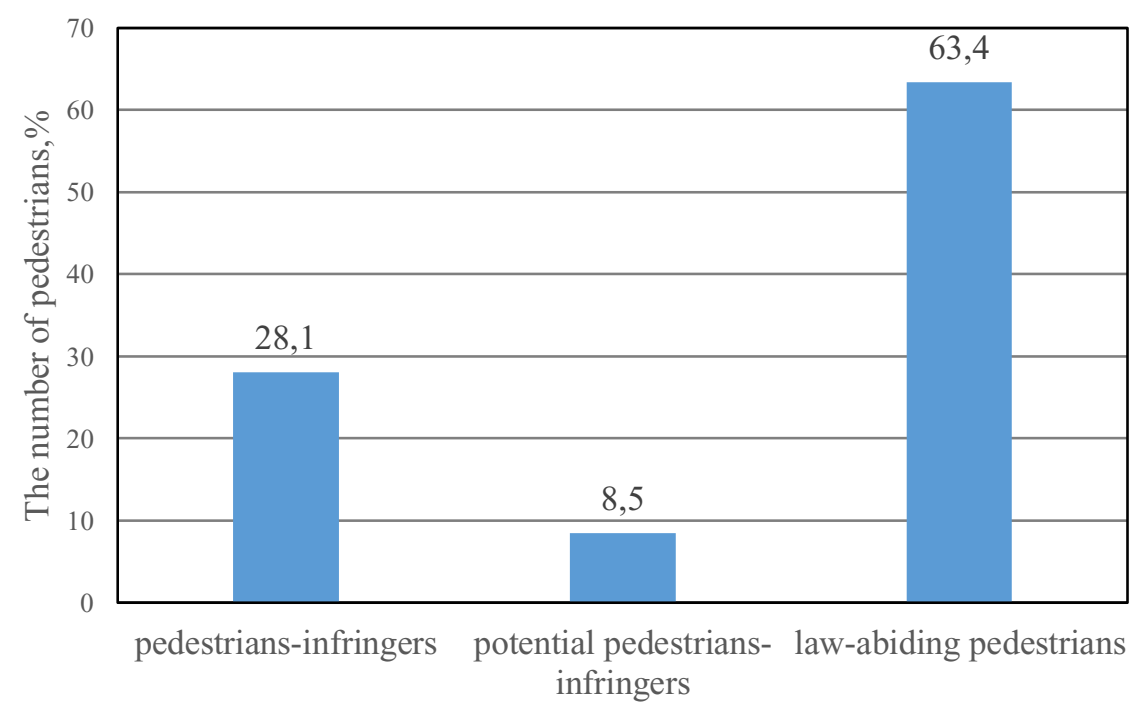

Fig. 2. The distribution on behavioral reactions when crossing the carriageway on crosswalks with humps.

It is necessary to allocate the group of potential pedestrians-infringers who actually can create danger at an exit to the carriageway. Pedestrians of this group look to the right at the right-hand traffic in our country on the sidewalk before the crossing, and to the left look already on the carriageway or do not look absolutely.

The way of crossing of the carriageway by pedestrians was fixed when carrying out a research also (fig. 3).

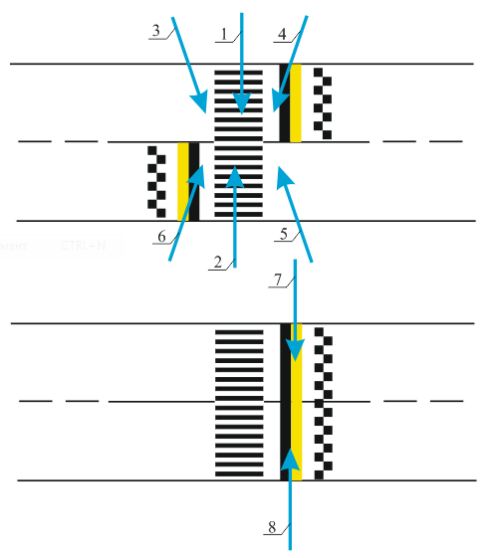

Fig. 3. Ways of crossing by pedestrians of the carriageway in zones of crosswalks with humps.

As a result, we have received that $8 \%$ of pedestrians cross the carriageway on trajectories 3 -6 and $92 \%$ - passed, according to the Traffic regulations. 
It should be noted that in places with accurate allocation of a approach zone to the crossing (the walking path is separated from the carriageway by a lawn, zones of approach are executed by a tile or are asphalted) all pedestrians passed the carriageway according to the Traffic regulations. In places where the approach zone to the crossing is a part of the sidewalk and it is not designated, for example, by a pedestrian protection, some pedestrians passed the carriageway near the designated crossing.

The calculation of a infringers share has been executed on the basis of the obtained data:

$$
\Delta n=\left(n_{o}+n_{i}\right) / n
$$

$n_{o}-$ the number of the pedestrians who have ignored danger;

$n_{i}-$ the number of the pedestrians crossing the carriageway not on the crosswalk;

$n$ - the number of measurements.

The annual number of violations on each the research object was determined by a formula:

$$
P_{o}=Q_{n} * \Delta n * F_{\mathrm{y}}
$$

$Q_{n}$ - the total pedestrians intensity on the crossing, people/h;

$\Delta n$ - a pedestrians-infringers share;

$F_{y}$ - annual fund of time, h/year (table 2).

Table 2. The pedestrians-infringers share and annual number of violations of the rules of crossing of the carriageway by pedestrians on research objects (Minsk, Belarus).

\begin{tabular}{|c|c|c|}
\hline The name of an object & $\begin{array}{c}\text { The share of the } \\
\text { pedestrians- } \\
\text { infringers }\end{array}$ & $\begin{array}{c}\text { Annual number of } \\
\text { violators, } \\
\text { violations/year }\end{array}$ \\
\hline st. N. Ordi, 11 & 0,14 & 90720 \\
\hline st. P. Brovki, 12/1 & 0,49 & 296352 \\
\hline st. Russiyanova, 48 & 0,34 & 210528 \\
\hline st. Odincsova, 65 & 0,23 & 92736 \\
\hline st. Y. Kolaca, 12 & 0,80 & 633600 \\
\hline st. Karbisheva, 13/2 & 0,20 & 112320 \\
\hline st. Kulmana, 22 & 0,06 & 45360 \\
\hline av. Pushkina, 19 (near school) & 0,31 & 99200 \\
\hline st. Bogdanovicha, 258 & 0,46 & 82800 \\
\hline st. Odoevskogo, 107 & 0,11 & 46200 \\
\hline st. Y.Kolasa, 18 & 0,29 & 214600 \\
\hline st. Hmelnicskogo, 47/1 & 0,68 & 83300 \\
\hline
\end{tabular}

\section{Summary}

It is necessary to pay attention to the social relations in the organization and management of traffic on the basis of the received results and also tendencies. Mistakes in a regulation of such relations can lead to considerable costs as their influence not only on social losses, but also on emergency, economic and, indirectly, on ecological, is obvious [13].

Within the executed research, it is possible to recommend the following:

$\checkmark \quad$ to accurately regulate installation sites of humps on streets categories and transport and pedestrian loadings;

$\checkmark \quad$ to fulfill precepts of law of the drivers and pedestrians communication. The accurate formulation of safety of a pedestrian exit to the carriageway is necessary. It is possible with constructive proposals on a street road network;

$\checkmark$ for decrease in number of violations (crossing not on the crosswalk) needs to be allocated accurately zones of an exit to the carriageway for pedestrians using structural elements or technical means of the traffic organization.

\section{References}


1. Y. Vrubel. Dangers in traffic (2013).

2. http://gaiminsk.by/statistika [date of access - 02.08.2016]

3. The traffic regulations of Republic of Belarus (2015).

4. D. Kapski, D. Mozalevski, M. Miroshnik, A. Korzhova, V. Kuzmenko, A.Polkhovskaya, E. Kostyukovich. The certificate No. 222 of 17.09.10 on registration of computer programs in the National center of intellectual property.

5. Y. Vrubel, D. Kapski, E. Kot. The definition of losses in the traffic (2006).

6. D. Kapski, S. Azemsha. The traffic security audit (2015).

7. D. Kapski, A. Korzhova, S. Skirkovsky. The transport in planning of the cities (2015).

8. P. Preston. A surge of the humps. Sleeping policemen sprout with the daffodils. But it's more to do with budgets than braking (2006).

9. http://www.ador.ru/data/files/static/audit_07.pdf. [date of access - 12.07.2016].

10. Vision Zero Initiative Traffic Safety by Sweden [electronic resource]. http://www.visionzeroinitiative. com/ru/concept [date of access - 19.03.2016].

11. The Project // Vision Zero Oregon Neighbors Working for Safer Streets [electronic resource]. http://www.visionzerooregon.org/the-project/ [date of access - 19.03.2016].

12. J. Whitelegg. Vision Zero: Adopting a Target of Zero for Road Traffic Fatalities and Serious Injuries (2006).

13. Y. Vrubel. Losses in traffic (2003). 